\title{
A pre- és probiotikumok használatának szabályozása az Európai Unióban és a világ más országaiban
}

\section{Tóth Szandra*}

Kaposvári Egyetem Agrár- és Környezettudományi Kar,

Mikotoxinok az Élelmiszerláncban Kutatócsoport, 7400 Kaposvár, Guba S. u. 40.

\begin{abstract}
Regulation of the use of pre- and probiotics in the European Union and in other countries of the world

Author(s): Szandra Tóth

Affiliation(s): Kaposvár Universty Faculty of Agricultural and Environmental Sciences, Mycotoxins in the Food Chain Research Group,7400 Kaposvár, Guba S. street 40., Hungary

It was sixteen years ago that recommendations and guidelines were worked out by the FAO/WHO about pre- and probiotics for professionals, industry and consumers (Pineiro and Ben Embarek, 2006). In the developed countries, conscious nutrition, health preservation and disease prevention are increasingly emphasized. In Regulation (EC) No 1831/2003 in the EU has forbidden the use of antibiotics in animal feed as a stimulant for growth. As a result of this decision, the research of health-preserving, disease-preventing products developed rapidly both in the food and feed industries. In order to avoid misuse of prebiotic and probiotic terms, it is necessary to regulate precisely the description of the products. Regulation (EU) 258/97/EC of the European Parliament and of the Council is the first time that the concept of novel foods and food ingredients was introduced. This is the regulation that for the time deals with the introduction of microorganism as food ingredient into the food chain. Pre- and probiotics are present in the food and feed industry due to their beneficial effects on the body, so the regulation of the two areas in many cases merges. A good example is Regulation (EC) 178/2002 of the European Parliament and of the Council, which provides both food, feed, safety conditions and also human and veterinary aspects. Food safety is an important issue for all countries in the world. Every country have an authority to made regulation within this important area, for example the EFSA in EU, the GRAS qualification in USA, the FOSHU category in Japan and the food safety regulation system in Canada. The ISAPP is an international scientific committee, who make guidelines about the usage of pre- and probiotics. This work provides insight to the EU's and other countries' food law regulations.
\end{abstract}

Keywords: EFSA, food law, prebiotics, probiotics

\section{ÖSSZEFOGLALÁS}

Tizenhat éve születtek meg a szakemberek, az ipar és a fogyasztók számára a FAO/WHO által készített ajánlások és irányelvek a pre- és probiotikumokról (Pineiro és Ben Embarek, 2006). Mindemellett a fejlett országokban egyre nagyobb társadalmi hangsúlyt kap a tudatos táplálkozás, az egészségmegőrzés és a betegségmegelőzés. Továbbá a 1831/2003/EK európai parlamenti és tanácsi rendeletben a Tudományos Operatív Bizottság betiltotta az antibiotikumok

\footnotetext{
*CORRESPONDING AUTHOR

Kaposvári Egyetem, Agrár - és Környezettudományi Kar

$\triangle 7400$ Kaposvár, Guba S. u. 40., 疋 +36-82-505-800

E-mail: toth.szandra@ke.hu
} 
hozamfokozó céllal történő felhasználását a takarmányokban. A döntés hatására rohamos fejlődésnek indult az antibiotikum kiváltására szolgáló, egészségmegőrző, betegség megelőző hatással bíró készítmények kutatása az élelmiszer- és takarmányiparban egyaránt. A prebiotikus és probiotikus fogalommal való visszaélés elkerülésének érdekében pontos szabályozásra van szükség a termékek leírására vonatkozóan. Az (EU) 258/97/EK európai parlamenti és tanácsi rendeletben jelenik meg első alkalommal az új élelmiszer és az új élelmiszer-összetevő fogalma. Ez a rendelet az, amely első ízben foglalkozik a mikroorganizmusok, mint élelmiszeralkotók élelmiszerláncba kerülésével. A pre- és probiotikumok a szervezetre gyakorolt jótékony hatásuknak köszönhetően jelen vannak az élelmiszer- és takarmányiparban egyaránt, így a két terület szabályozása sok esetben összeolvad. Erre jó példa a 178/2002/EK európai parlamenti és tanácsi rendelet, amely egyaránt rendelkezik az élelmiszerellátásról, takarmányozásról, ezek biztonsági feltételeiről valamint humán és állategészségügyi aspektusokról. Az élelmiszerbiztonság a világ minden országában fontos tényező. Minden ország rendelkezik olyan hatósággal, amelynek feladata az ide vonatkozó szabályok megteremtése, betartatása, felülvizsgálata. Az EU-ban az EFSA által hozott rendeletek, az USA-ban a GRAS minősítés, Japánban a FOSHU kategóriára vonatkozó rendelkezések, míg Kanadában az élelmiszereket érintő biztonsági értékelési rendszer. Az International Scientific Association of Probiotics and Prebiotics (ISAPP) pedig egy olyan nemzetközi tudományos társaság, amely segít a pre- és probiotikumok használatára vonatkozó tudományos szakvélemények megalkotásában. Jelen áttekintés segít bepillantást nyerni az EU és más országok élelmiszer- és takarmányjogi szabályozásának rendszerébe és azok kialakulásába.

(Kulcsszavak: EFSA, élelmiszerjog, prebiotikum, probiotikum)

\section{BEVEZETÉS}

A pre- és probiotikumok a táplálkozástudomány fejlődésével, az egészséges életmód előtérbe kerülésével jelentek meg a köztudatban és kapnak folyamatosan növekvő szerepet, létezésük nem új keletű a tudomány számára. A modern orvostudomány megalapítójától, a görög Hipokratésztől származik a mondás, miszerint: „Minden betegség a bélből ered”. A mikroorganizmusok felfedezését a holland Antonie van Leeuwenhoeknak tulajdonítják, aki az 1600-as évek második felében elsőként nemcsak megfigyelt, hanem le is írt mikroorganizmusokat. Saját készítésű mikroszkópja segítségével felfedezte a szájüregben élő mikróbákat és ezzel a mikrobiológiai kutatások atyjává vált. A 
19. században az orosz származású Nobel-díjas biológusnak Ilja Mecsnyikovnak sikerült bizonyítania, hogy a bél mikroflórája szoros összefüggésben áll az egyén élethosszával. Leghíresebb mondata is ebből az időből származik: „A halál a vastagbélben kezdődik". Miután megszületett a felismerés, miszerint az emésztőtraktusban található mikrobióta sejtek nem csupán az emésztés során elpusztult sejtalkotók, előtérbe kerültek a pre- és probiotikumok fontosságára irányuló kutatások (Floch és mtsai, 2018). Mecsnyikov írt elsőként joghurtban található tejsavbaktériumról, amit Lactobacilus bulgaricusnak nevezett el. A probiotikum szót mai értelmében vett kifejezésként először R. B. Parker használta (Parker, 1974). Probiotikumok azok az élő mikroorganizmusok, amelyek a bélrendszer mikrobióta egyensúlyáért felelősek, ellenállnak a gyomorsav, az epe, a nyál, a hasnyálmirigy és a bélnedvek emésztőenzimeinek, nem sérülnek az élelmiszer előállításban alkalmazottgyártástechnológiai eljárások során sem. A leggyakrabban előforduló probiotikus baktériumok a Lactobacillus és a Bifidobacterium törzsekbe tartoznak.

A prebiotikum szó a görög pre és bios szavak összeolvadásából keletkezett mozaikszó, amelynek jelentése 'életért'. Az elnevezés találó, hiszen a prebiotikumok a fent említett mikroorganizmusoknak jelentenek kizárólagos táplálékot, mivel a vékonybélben nem emésztődnek, így változás nélkül jutnak el a vastagbélbe, hogy ott táplálékul szolgáljanak az ott élő probiotikus törzseknek, elősegítve ezzel azok szaporodását. Ide tartoznak a nem keményítő eredetű poliszacharidok (NSP), mint a cellulóz, hemicellulóz, gumi, pektin, valamint az oligoszacharidok, mint például az inulin. A legújabb kutatási eredmények szerint, a bélnyálkahártya felszínén élő bélflóra az alábbi élettani funkciókban nélkülözhetetlen: táplálék emésztése és tápanyag felszívódás, patogénekkel szembeni küzdelem, méregtelenítés, immunrendszer működése, enzimek, vitaminok és neurotranszmitterek termelése, endokrin rendszerre kifejtett hatás, gyulladásos folyamatok mérséklése (Loveren és mtsai, 2012; Hill és mtsai, 2014; Perlmutter és Loberg, 2017)

A fejlett országokban egyre nagyobb társadalmi hangsúlyt kap a tudatos táplálkozás, az egészségmegőrzés és betegségmegelőzés. Az antibiotikum rezisztencia kialakulásának növekvő veszélye miatt a 1831/2003/EK európai parlamenti és tanácsi rendeletben a Tudományos Operatív Bizottság betiltotta az antibiotikumok hozamfokozó céllal történő felhasználását a takarmányokban. A döntés hatására rohamos fejlődésnek indultak az antibiotikum kiváltására szolgáló, kedvező élettani hatással bíró anyagok kutatása. Ebbe az irányvonalba jól beilleszthetőek a pre- és probiotikumok. Hangsúlyozni kell azon- 
ban, hogy ezeknek a kiegészítő- és adalékanyagoknak jó része már az antibiotikum használat korlátozása előtt is forgalomban volt, de szerepük az élelmiszeripari trendekben bekövetkező változások miatt felértékelődött. Sajnálatos módon a probiotikus fogalommal való visszaélés szintén jelentős kérdéssé vált, mivel sok termék esetében használták a kifejezést anélkül, hogy azok megfeleltek volna a szükséges kritériumoknak (Hill és mtsai, 2014). Az élelmiszerbiztonság a világ minden országában fontos tényező. Minden ország rendelkezik olyan hatósággal, amelynek feladata az ide vonatkozó szabályok megteremtése, betartatása, felülvizsgálata. A pre- és probiotikumok a szervezetre gyakorolt jótékony hatásuknak köszönhetően jelen vannak az élelmiszer- és takarmányiparban egyaránt. Mivel a takarmányipar jellemzően élelmiszer előállítás céljából tartott állatok etetésére szánt termékek előállításával foglalkozik, a két terület szabályozása sok esetben összeolvad.

Jelen áttekintés segít bepillantást nyerni elsősorban az EU-tagállamok, illetve más országok élelmiszer- és takarmányjogi szabályozásának rendszerébe és azok kialakulásába.

\section{AZ EURÓPAI UNIÓ JOGALKOTÁSA}

Egyes szakpolitikai területeket az EU és a tagállamok közösen szabályoznak. De a tagállamok csak abban az esetben hozhatnak törvényeket, ha az EU nem szabályozta az adott területet, illetve úgy határozott, hogy nem kívánja szabályozni azt. A megosztott hatáskörbe tartozó területek közé tartozik a mezőgazdaság, a környezetvédelem, a fogyasztóvédelem, a kutatás és a közegészségügy is. A pre- és probiotikumok piaci megjelenésének, takarmányozási vagy humán célú felhasználásának szabályozásában legnagyobb szerepe az élelmiszerbiztonsággal kapcsolatos rendelkezéseknek van. Ezek együttes érdeke a közös piac fogyasztóinak védelme, egységes tájékoztatása, a piaci szereplők egyenlő versenyhelyzetének biztosítása.

\section{Az élelmiszerekre vonatkozó jogi szabályozások.}

Az (EU) 89/107/EGK európai parlamenti és tanácsi irányelvében megfogalmazta aggályait az élelmiszeradalék anyagok közös szabályozásának a hiányával kapcsolatban. Előterjesztette az ide vonatkozó anyagok nemzeti szabályozásainak közelítését, amelynek célja, az EU piaci szereplőinek egységesítése minden tagállamban. Bár ebben az irányelvben még nem szerepelnek a pre- és probiotikumok mint élelmiszeradalék anyagok, a dokumentum fontos lépést jelent a későbbi szabályozási rendszerek kialakulásában. Az irányelvet a 2010- 
ben megjelent,az (EU) 1333/2008/EK Élelmiszer adalékanyagokról szóló európai parlamenti és tanácsi rendelete helyezte hatályon kívül. Az új rendelet pontos iránymutatást nyújt az adalékanyagok csoportosításáról, illetve fogalom meghatározásáról. Azonban kijelenti, hogy az inulin és az oligoszacharidok nem tartoznak az adalékanyagok közé. Ezzel lényegében a prebiotikumokat kizárja az élelmiszeradalék-anyagok és az ide vonatkozó jogszabályok sorából.

Az EU élelmiszerellátásról, takarmányozásról, az ezek biztonságát megteremtő feltételekről és az ide vonatkozó humán és állategészségügyi aspektusokról szóló jelenleg hatályos alapvető rendelkezései az (EU) 178/2002/EK európai parlamenti és tanácsi rendeletben olvashatóak. A rendelet szerint a tapasztalatok azt mutatják, hogy szükség van olyan intézkedések bevezetésére, amelyek garantálják, hogy a nem biztonságos élelmiszerek ne kerülhessenek a piacra, és biztosítják, hogy legyenek olyan rendszerek, amelyek felismerik az élelmiszerbiztonsági problémákat és a belső piac megfelelő működése, illetve az emberi egészség védelme érdekében megteszik az ellenintézkedéseket.

A takarmánybiztonsággal kapcsolatos hasonló problémákat is meg kellett oldani. Ezért az (EU) 178/2002/EK rendeletben az EU létrehozta az Európai Élelmiszerbiztonsági Hatóságot (EFSA), amely az élelmiszerek és a takarmányok tudományos ellenőrzéséhez és értékeléséhez nyújt támogatást, rendelkezik az élelmiszerjog általános elveiről és követelményeiről valamint az élelmiszerbiztonságra vonatkozó eljárások megállapításáról. Az EFSA, az Európai Bizottság és a tagállamok együttműködnek, annak érdekében, hogy elősegítsék a kockázatértékelés, a kockázatelemzés és a kockázati kommunikáció tényleges egységének megteremtését. Az EFSA feladata továbbá tudományos szakvélemények készítése állat-egészségügyi, állatvédelmi és növény-egészségügyi kérdésekben. Az EFSA hatásköre magában foglalja jogelődjének, az (EU) 93/5/EGK tanácsi irányelve által életre hívott Élelmiszerügyi Tudományos Bizottságnak munkáját, így az, az (EU) 2004/210/EK európai parlamenti és tanácsi rendelet értelmében megszűnik. Az Európai Bizottság (2001) szerint az (EU) 178/2002/EK rendelet az alapja egy átfogó, integrált megközelítésnek az élelmiszer-ellátási lánc szabályozásában. Ebben a rendeletben jelenik meg első alkalommal a „szántóföldtől az asztalig” névvel illetett koncepció, amely magában foglalja a nyomonkövethetőséget, az átláthatóságot és a biztonságot. Az egészségre és a táplálkozásra vonatkozó állításokról szóló rendeletek célja annak biztosítása, hogy a fogyasztókat ne tévesszék meg az élelmi- 
szertermékekre vonatkozó, megalapozatlan, eltúlzott vagy valótlan állításokkal (Loveren és mtsai, 2012). A jelenlegi jogszabályok értelmében a fogyasztóknak megfelelő tájékoztatást kell kapniuk az általuk választott élelmiszerről. Ez a megközelítés az egészségesebb életmóddal kapcsolatos kampányhoz, valamint a Bizottság fogyasztóvédelmi célkitűzéseihez kapcsolódik (Loveren és mtsai, 2012). Az (EU) 178/2002/EK rendelet határozza meg az élelmiszerjog fogalmát is, amely a következő: általában az élelmiszerekre és különösen az élelmiszerek biztonságára vonatkozó, a Közösségben vagy az egyes tagállamokban elfogadott törvények, rendeletek és közigazgatási rendelkezések. Az élelmiszerjog fogalma vonatkozik az élelmiszerek, valamint az élelmiszertermelés céljára tenyésztett állatok takarmányozására használt takarmány termelésének, feldolgozásának és forgalmazásának minden szakaszára is. Az (EU) 178/2002/EK rendelet bizonyos aspektusai módosításon és pontosításon estek át a tudomány, a fogyasztói igények, és a technológia fejlődésének köszönhetően.

\section{Fogyasztóvédelem és a termékmegjelenés uniós szabályozása}

Az (EU) 1924/2006/EK európai parlamenti és tanácsi rendelet az élelmiszerekkel kapcsolatos, táplálóanyag-összetételre és egészségre vonatkozó állításokkal foglalkozik. Ez a rendelet fontos továbbfejlesztése az (EU) 90/496/EGK tanácsi irányelvnek, amelyet az (EU) 1169/2011/EK európai parlamenti és tanácsi rendelet hatályon kívül helyezett. A rendelet létrejöttének magyarázata a következő: „Az élelmiszerekben számos olyan tápanyag vagy egyéb anyag beleértve, de nem kizárólag, a vitaminokat, ásványi anyagokat (beleértve a nyomelemeket is), aminosavakat, esszenciális zsírsavakat, élelmi rostokat, különféle növényi és gyógynövénykivonatokat - fordulhat elő, amelyek táplálkozási vagy élettani hatással bírnak, és ilyen állítás tárgyát képezhetik. Ezért meg kell határozni az élelmiszerekre vonatkozó valamennyi általános elvet annak érdekében, hogy biztosítható legyen a magas szintű fogyasztóvédelem és a fogyasztó megkapja a tények teljes ismeretében történő választáshoz szükséges információkat, valamint hogy biztosítottak legyenek az élelmiszeriparon belüli verseny egyenlő feltételei. Az egyes tagállamokban az élelmiszerek címkézésekor és reklámozása során számos esetben használnak fel olyan állítást, amely nem igazolt, vagy amelyeket illetően pillanatnyilag nincsen kellő tudományos egyetértés. Biztosítani kell, hogy az anyag, amelyre az állítás vonatkozik, valóban rendelkezzen kedvező táplálkozási vagy élettani hatással. Az állítások valóságtartalmának biztosítása érdekében szükséges, hogy az anyag, amelyre az állítás vonatkozik, elegendő mennyiségben legyen jelen a késztermékben. Az 
anyagnak a szervezet számára hasznosítható formában kell jelen lennie. Ezenfelül - adott esetben - az ésszerűen várható elfogyasztandó élelmiszer-menynyiségnek megfelelő mennyiségben tartalmaznia kell a jelzett táplálkozási és élettani hatást kiváltó anyagot." Az (EU) 1924/2006/EK rendelet 2. cikkében meghatározza az „egészségre vonatkozó állítás” fogalmát, amely megegyezik bármely olyan állítással, amely kijelenti, sugallja vagy sejteti, hogy adott élelmiszer, élelmiszercsoport vagy annak valamely alkotóeleme és az egészség között összefüggés van. Adott élelmiszer címkézésén vagy reklámján a tápanyagösszetételre és egészségre vonatkozó állításokat csak akkor lehet az európai közösségen belül alkalmazni, ha megfelelnek az (EU) 1924/2006/EK rendelet 3. cikkében foglalt előírásoknak, amelyek a következőek:

- nem lehet valótlan, félreérthető vagy megtévesztő;

- nem kelthet kétséget más élelmiszerek biztonságos voltát és/vagy táplálkozásra való alkalmasságát illetően;

- nem ösztönözheti vagy helyeselheti egy adott élelmiszer túlzott fogyasztását;

- nem jelentheti ki, sugallhatja vagy sejtetheti azt, hogy a kiegyensúlyozott és változatos étrend általában nem biztosítja a tápanyagok megfelelő mennyiségét. A 24. cikk (2) bekezdésében említett eljárással összhangban - figyelembe véve a tagállamokban fennálló sajátos körülményeket - eltéréseket lehet elfogadni - beleértve alkalmazásuk feltételeit is - azon tápanyagok esetében, amelyekből a kiegyensúlyozott és változatos étrend nem biztosítja a megfelelő mennyiséget;

- nem utalhatnak sem szövegesen, sem képi, grafikus vagy szimbolikus ábrázoláson keresztül a testi funkciók olyan változásaira, amelyek a fogyasztóban félelmet kelthetnek, és nem használhatják ki a fogyasztó félelmét;

Ugyanezen rendelet 5. és 6. cikke foglalja össze az egészségre vonatkozó állítások indokoltságát, illetve az erre irányuló tudományos igazolások meglétének biztosítását. A rendelet mellékletében található az élelmirost-forrás és az élelmi rostban gazdag kifejezések pontos definíciója. Az élelmirost-forrás olyan élelmiszer leírásában alkalmazható, amelyben az élelmirost-tartalom legalább 3g/100g vagy 3g/100 kcal. Élelmi rostban gazdag az az élelmiszer, amelyben az élelmirost-tartalom ennek a duplája, azaz 6g/100g vagy 6g/100 kcal. 


\section{A pre- és probiotikumok megjelenése az EU élelmiszerjogi szabályozásá- ban}

Az (EU) 258/97/EK európai parlamenti és tanácsi rendeletben jelenik meg első alkalommal az új élelmiszer és az új élelmiszer-összetevő fogalma. Ez a rendelet az, amely első ízben foglalkozik a mikroorganizusok, mint élelmiszeralkotók élelmiszerláncba kerülésével. Az EU szabályozás értelmében az újszerủ élelmiszer az, amelyet nem használtak 1997. május 15-e előtt. Ez a rendelet egyértelműen meghatározza a szükséges kockázatértékelési lépéseket az új élelmiszerek EU-piacon való bevezetését megelőzően történő engedélyezésre. Ez a szabályozás 2013 decemberében felülvizsgálatra került, majd 2018. január 1-től hatályba lépett a módosításokat tartalmazó (EU) 2015/2283/EK európai parlamenti és tanácsi rendelet. A változás a 3. országból érkező tradicionális élelmiszerekre, a nanotechnológiára és a kérelmek benyújtására, értékelésére vonatkoznak. A szabályozás értelmében, a tagállam erre felállított bizottsága vagy az Európai Élelmiszerbiztonsági Hatóság (EFSA) és az Európai Bizottság adhat értékelést azon élelmiszerekről és összetevőkről, amelyek Európán belüli biztonságos használatáról nem volt leírás 1997 előtt, ezért "újszerü"-nek tekinthetőek. A rendeletben rendelkeznek a mikrooganizmusokról: külön kategóriákat kell létrehozni az új vagy szándékosan módosított molekulaszerkezettel rendelkező élelmiszerek, az állatokból, növényekből, mikroorganizmusokból, gombákból vagy algákból származó sejt- vagy szövetkultúrából előállított élelmiszerek, a mikroorganizmusokból, gombákból vagy algákból előállított élelmiszerek, valamint az ásványi eredetű anyagból előállított élelmiszerek számára.A rendelet egyúttal megköveteli az élelmiszer vagy összetevő széles körű biztonsági értékelését az EU piacára való átvétel elött. Az újszerü élelmiszereket és alapanyagokat tartalmazó lista elérhető az Európai Bizottság nyilvántartó hivatalának oldalán, akárcsak a szabályozásra és felhasználásra vonatkozó ajánlások és előírások. A hozzáadott baktériumokat tartalmazó élelmiszerek szintén „újszerü” élelmiszernek számítanak, amelyekről évente frissülő lista érhető el (QPS, Qualified Presumption of Safety of Micro-Organism in Food and Feed). Ez a lista az Európai Unión belül elérhető és biztonságosnak ítélt mikroorganizmusokat tartalmazza (EFSA, 2013). Új élelmiszer anyagok fejlesztésénél az Európai Új Élelmiszer Szabályzatban leírtaknak megfelelő élelmiszerbiztonsági előírásokat veszik alapul, majd az így készült értékelés alapján az Európai Bizottság hoz döntést az új élelmiszer alapanyag biztonságáról és elfogadásáról (Kumar és mtsai, 2015). 


\section{Takarmányozással és takarmány adalékanyagokkal kapcsolatos rendel- kezések az EU-ban.}

Takarmány összetevőkkel már 1970-ben, az (EU) 70/524/EGK tanácsi irányelv is foglalkozott, ám azóta a szabályok felülvizsgálatára volt szükség. Ennek oka egyrészről az emberi és állati egészség és a környezet nagyobb fokú védelmének biztosítása, másrészről pedig a technológia és a tudomány fejlődése. Az irányelvet az (EU) 1831/2003/EK rendelet sok szempontból frissítette. Végül 2010.09.01-el lépett hatályba a takarmányok forgalomba hozataláról és felhasználásáról szóló jelenleg hatályos (EU) 767/2009/EK európai parlamenti és tanácsi rendelet, amely hatályon kívül helyezte az (EU) 70/524/EGK irányelvet és módosította az (EU) 1831/2003/EK rendeletet. Az (EU) 767/2009/EK rendelet 13. cikkében foglalkozik a termék jelölő címkéjén lévő állításokkal. Az itt található 1. pont szerint „a takarmány-alapanyag és az összetett takarmány címkézése és kiszerelése felhívhatja a figyelmet egy bizonyos anyag takarmányban való meglétére vagy hiányára, különleges táplálkozási jellemzőkre vagy folyamatra". Ugyanezen rendelet IV. mellékletének 4. pontjában rendelkezik a mikroorganizmusok csoportjába tartozó takarmány-adalékanyagokra vonatkozó megengedhető felső határról, amely a rendeletben rögzített maximális értékkel egyenértékű. A 8. cikkben a rendelet meghatározza a takarmány-adalékanyag és a kiegészítő takarmány maximális szintjét, amely nem lehet több mint a teljes értékű takarmány esetében rögzített maximális adalékanyag-tartalom százszorosa vagy a kokcidiosztatikum- és hisztomonosztatikum-tartalom ötszöröse. A VI. mellékletben foglaltak szerint a címkén fel kell tűntetni az adalékanyagokat az engedélyezésükre vonatkozó jogszabályban szereplő konkrét nevük, hozzáadott mennyiségük, azonosító számuk, valamint az (EU) 1831/2003/EK rendelet I. melléklete szerinti funkcionális csoportjuk vagy ugyanezen rendelet 6 . cikkének (1) bekezdésében említett kategóriájuk megadásával. A „takarmány-adalékanyag”, „előkeverék”, „technológiai segédanyag” és a „napi adag” fogalmak meghatározása is az (EU) 1831/2003/EK rendelet szerint történik. A rendelet I. mellékletében foglaltak szerint 4 csoportba sorolhatóak az adalékanyagok, amely csoportok további alegységekre bonthatóak. A pre-és probiotikumok a 4. csoport b) alcsoportjához tartoznak a következő besorolás szerint.

1. technológiai adalékanyagok,

2. érzékszervi tulajdonságokat javító adalékanyagok,

3. tápértékkel rendelkező adalékanyagok,

4. állattenyésztésben alkalmazott adalékanyagok, 
a. emészthetőséget fokozó anyagok,

b. bélflóra-stabilizálók: mikroorganizmusok vagy egyéb kémiailag meghatározott anyagok, amelyek az állatokkal megetetve pozitív hatást gyakorolnak a bélflórára,

c. a környezetre kedvező hatást gyakorló anyagok,

d. egyéb állattenyésztésben alkalmazott adalékanyagok.

A III. melléklet kimondja, hogy a mikroorganizmusok esetében a következő adatokat kell feltüntetni a címkézés során:

- a szavatosság lejárati ideje, vagy a gyártás időpontjától számított eltarthatósági idő,

- a használati utasítás,

- a törzs azonosítási száma, és

- a telepképző egységek száma grammonként.

Az (EU) 1831/2003/EK rendelet kimondja, hogy a takarmány-adalékanyagokról az EFSA-nak kell tudományos értékelést készítenie, ez az alapja a forgalomba helyezésnek. Azon anyagokra, amelyek már rendelkeznek a korábbi, az (EU) 89/107/EGK irányelv alapján elvégzett engedélyezi eljárással, egy egyszerűsített eljárás vonatkozik. A rendelet 22. pontja értelmében létre kell hozni az engedélyezett takarmány-adalékanyagok nyilvántartását, amely termékspecifikus információkat és kimutatási módszereket is tartalmaz. 2000 és 2015 között számos mikroorganizmusokkal foglalkozó végrehajtási rendelet látott napvilágot, ugyanis minden egyes mikroorganizmus minden egyes törzsére különálló engedélyezési eljárás készül, hiszen a probiotikumok különféle törzsei eltérő válaszreakciót idéznek elő a szervezetben még akkor is, ha a generikus nevük ugyanaz az (Floch és mtsai, 2018). Ezért a specifikus törzseket megfelelően azonosítani kell. Az engedélyezési eljárások közül van, amelyik határozott és van határozatlan idejű. A határozott idejű rendeleteket 4-10 évente (a határidő lejártával) az EFSA felülvizsgálja és további rendeletben határozza meg a takarmány-adalékanyag használhatóságát. A rendeletek meghatározzák azt is, hogy a takarmányadalék-anyagot mely állatfajokban lehetséges használni. Amennyiben a kutatások úgy ítélik meg, hogy az adott anyag más állatfajok termelésére is pozitív hatással lehet, kérvényezik az adott anyag használhatóságának kiterjesztését. Az EFSA a megfelelő vizsgálatok és kockázatértékelések elvégzése utáni határozatát szintén rendeletben rögzíti. Ennek jó példája az (EU) 1810/2005/EK bizottsági rendelet, amelynek 10-es pontja kimondja, hogy „az Enterococcus faecium (NCIMB 11181) mikroorganizmus- 
készítmény alkalmazását az (EU) 1333/2004/EK bizottsági rendelet határozatlan időre engedélyezte a borjú és a malac vonatkozásában. Új adatokat nyújtottak be az ezen mikroorganizmus-készítmény engedélyezésének a brojlercsirkére való kiterjesztése iránti kérelem alátámasztása céljából. Az Európai Élelmiszer-biztonsági Hatóság (EFSA) 2005. április 13-án kedvező véleményt nyilvánított az adalékanyag biztonságosságára vonatkozóan, amennyiben azt a brojlercsirke-állatkategóriában és a IV. mellékletben meghatározott feltételek szerint alkalmazzák. A vizsgálat azt mutatja, hogy az (EU) 70/524/EGK irányelv 9 e. cikkének (1) bekezdésében az ilyen engedélyezésre előírt feltételek teljesülnek. Ennek megfelelően ezen mikroorganizmus-készítmény felhasználását a IV. mellékletben meghatározottak szerint ideiglenesen, négy évre engedélyezni kell". Az (EU) 1810/2005/EK rendelet 11-es pontja ugyanilyen okokból kéri az Enterococcus faecium (CECT 4515) mikroorganizmus-készítmény alkalmazásának kiterjesztését brojler csirkére. Ebből a példából jól látszik, hogy mind a mikroorganizmusok törzsei, mind a különféle állatfajok egyedi elbírálás alá tartoznak, amelyek nem örök érvényűek, időnkénti felülbírálást igényelnek.

\section{SZABÁLYOZÁSI MÓDOK A VILÁG MÁS TÁJAIN}

Tizenhét év telt el a pre- és probiotikumok nemzetközileg elfogadott, hivatalos fogalmának megalkotása óta. Tizenhat éve születtek meg a szakemberek, az ipar és a fogyasztók számára a FAO/WHO által készített ajánlások és irányelvek e témában (Pineiro és Ben Embarek, 2006).

A probiotikum definíciója szerte a világon ma is a legpontosabb megfogalmazás (Hill és mtsai, 2014) vagyis a probiotikum olyan élő mikroorganizmus, amely megfelelő mennyiségben a szervezetbe juttatva pozitívan járul hozzá a gazdaszervezet egészségéhez (Floch, 2018). Pontosabb megfogalmazások esetén ezt az állítást Fuller (1989) megjegyzésével egészítik ki, miszerint a probiotikumok fokozzák a bél mikrobiális egyensúlyát. A prebiotikumok meghatározásában mai napig Gibson és Roberfroid (1995) munkáját tartják alapvetőnek, amely szerint „a prebiotikumok nem emészthető étrendi alkotók, amelyek jótékonyan hatnak a gazdaszervezetre azáltal, hogy szelektíven befolyásolják a bél mikrobiótáinak szaporodását és/vagy aktivitását". Tudományos közleményekben ezt az állítást Trowell és mtsai (1985) megfogalmazásával egészítik ki, amely szerint a prebiotikumok összességében nem keményítő eredetű növényi poliszacharidok, amelyek emberi emésztőenzimek számára emészthetetlenek. Ez egy egyszerű, de jó definíció, és magában foglalja a sejtfal anyagokat, például a cellulózt, a hemicellulózt, a pektint, a lignint, valamint az 
intracelluláris poliszacharidokat, például a gumikat és a nyálkákat. Ezek a definíciók nagyon fontosak, hiszen sok vita és félreértés van ezen anyagok körül, éppen ezért fontos észben tartani ezen anyagok pontos eredetét és meghatározását (Hill és mtsai, 2014). A Pro- és Prebiotikumok Nemzetközi Tudományos Társasága az ISAPP, egy nemzetközi nonprofit szervezet a pre- és probiotikumok tudományos értékelésének előmozdítására. Működésének szabályozását világszintű tudományos kutatók által vezetett igazgató tanács látja el. Az ipari fejlesztésekben, mint Ipari Tanácsadói Szövetség van jelen. Az ISAPP igyekszik objektív, tudományos egyetértésen alapuló nyilatkozatokat tenni a pre- és probiotikumok témájában, amellyel segíti a nemzeti és nemzetközi szabályozásokat világszerte (Hill és mtsai, 2014). Az ISAPP 2014-es konszenzusi ülésén megfogalmazottak szerint (Hill és mtsai, 2014) meg kell különböztetni azokat az élő mikrobiótákat amelyek segédanyagként vagy hasznos vegyületek anyagaiként használnak, azoktól amelyek elsősorban jótékony egészségügyi hatásukról ismertek. Ez a meghatározás a nem patogén, kommenzalista mikrobióták és a probiotikumok közti különbséget is megadja. Habár, a kommenzlista mikrobióták a bélben szintúgy probiotikus törzsek forrásai, attól még addig, amíg ez a törzs nincs elkülönítve, pontosan meghatározva és jótékony egészségügyi hatása feljegyezve, addig nem nevezhető probiotikumnak. Nyilvánvaló, hogy a probiotikus fogalom különböző értelmezései jelentős előnyökkel járnak a főbb érdekeltek számára. A probiotikumok elterjedésének négy érdekelt csoportja van, amelyek célja is eltérő:

- Tudomány: magas tudományos minőséggel bíró anyag előállítása, felismerése, amely a társadalom javát szolgálja;

- Gyártó: magas minőségü, megtérülő termékek eloállítása, amelyek elismert és egyértelmü hatással bírnak;

- Felhasználó: döntéshozatalban segítő információk, hatások leírásának elvárása;

- Szabályozói szervek: fogyasztók védelme a félreinformálástól.

A probiotikumok fejlesztésében és elterjesztésében mind a négy résznek egy közös célon kell dolgozni. Az ISAPP 2014-es ülésén fogalmazta meg aggályait a pre- és probiotikumok piaci szereplésével és szabályozásával kapcsolatban. Ezek szerint a piaci forgalomban nagyon sok termék viseli a probiotikus jelzőt, bár sok esetben ezek leírása nem felel meg a minimum követelményeknek, mint például a pontosan megnevezett probiotikus alkotó, a szavatossági idő végén jelen lévő életképes telepképző egység mennyisége, illetve a fogyasztással járó jótékony egészségügyi hatások felsorolása. Valójában, leginkább tiszta 
kommunikációra van szükség a vásárlók és az egészségügy felé, annak érdekében, hogy felismerjék a különbséget a probiotikus termékek között. Ez a feladat nem egyszerü, hiszen a szabályozó hatóságok szigorú előírásokban határozzák meg, mit tartalmazhat a termék leírást tartalmazó címke. Amennyiben a címkére vonatkozó minimális kritériumok teljesülnek, az élelmiszerekben előforduló probiotikus anyagok leírásának szabályozása nem kielégítő az EU országaiban (Hill és mtsai, 2014).

Az Amerikai Egyesült Államokban (USA) a szabályozási folyamatok más gondolkodásmódra épülnek. Míg Európában az engedélyezés feltételezi a teljes bizonyosságot a termék használatának biztonságáról, addig az USA-ban az engedélyezés feltétele, a használat során felmerülő ártalom hiánya. Kumar és mtsai (2015) az újszerű élelmiszerek megjelenéséről és szabályozásáról szóló értekezésükben a következőképpen írtak az USA-ban érvényben lévő szabályozási folyamatokról: „Az Egyesült Államokban az élelmiszerek és az élelmiszer-összetevők szabályozását az Élelmiszer- és kozmetikai törvény (FDCA) szabályozza. Az új és újszerú élelmiszerek biztonságáért az USA-ban elsősorban az élelmiszer előállító felelős. A szabályozás értelmében minden olyan anyag, amelyet szándékosan az élelmiszerhez vagy takarmányhoz kevernek, adalékanyagnak minősül, amelyet az FDA előzetesen felülvizsgált és jóváhagyott, kivéve, ha az az anyag szakképzett szakértők körében általánosan elismert és általuk felhasználásra javasolt. Az USA-ban a pre- és probiotikumokat ugyanúgy szabályozzák, mint az összes többi élelmiszer összetevőt, vagyis a gyártó saját belátása szerint élelmiszer-adalékanyagként vagy úgynevezett „Általánosan Biztonságosnak Tekintett Anyag”-ként (GRAS) hozhatja forgalomba. A GRAS minősítés biztosításához két feltétel szükséges. Az egyik, hogy a biztonságos használatról szóló információk elérhetőek legyenek a tudományos szakértők számára, amely a szakértői vélemény tudományos publikálását jelenti. Másodsorban pedig az anyag biztonságos használatának általános elfogadása szükséges a tudományos közösségben. Az FDA nem rendelkezhet meghatározó előírással a GRAS anyagokról, csupán ajánlást tehet. A GRAS minősítést létrehozó törvény (FDCA, 1958-Az Élelmiszer Adalékok Módosításáról) kifejezetten kizárta az FDA-t az ilyen típusú adalékanyagok élelmiszer-ellátásban történő megjelenésének szabályozásából. A GRAS státus felállítását tehát szakképzett tudósok végzik, akik véleménye alapján a rendeltetésszerű használat során a termék biztonságosnak tekinthető. A probiotikumokat nagyon régóta használják az élelmezés során táplálék-kiegészítőként. Amennyiben az élelmiszer előállítása során az alapanyag vagy a technológiai eljárás tartalmaz 
mikroorganizmusokat, azt nem kell külön táplálék-kiegészítőként kezelni. Tehát az új probiotikumok piaci érvényesüléséhez előbb meg kell szerezni a GRAS engedélyt, hogy lehetőséget kapjanak az élelmiszerekben történő megjelenéshez, majd ezt követően lehet őket táplálék-kiegészítőként szélesebb körben alkalmazni."

Japánban a pro-és prebiotikumok jogszabályban rögzített kategorizálása az EU-ban és USA-ban megfigyelt gyakorlattól szélesebb körü. Az élelmiszerek és takarmányozásra szánt anyagok a következő három csoport valamelyikébe tartoznak (Kumar és mtsai, 2015):

- $\quad$ speciális táplálkozási célokat kielégítő élelmiszerek: a terhes nőkre, csecsemőkre és diszfágiában szenvedőkre terápiásan ható élelmiszerek;

- $\quad$ speciális egészségügyi hatással bíró élelmiszerek (Foods for Specified Health Uses, FOSHU): ezek a termékek betegség csökkentő hatással bírnak;

- $\quad$ étrendi hatással bíró összetevők.

A FOSHU kategória a következő megállapításokkal bír:

- Aktívan befolyásolják a test fiziológiás folyamatait és biológiai aktivitását.

- Napi használatukkal a kívánatos egészségügyi hatás elérhető.

- Egyedi értékelés alá tartozó élelmiszer termékek, amelyek rendelkeznek a megfelelő biztonsággal, minőséggel, érvényességgel valamint a kormányzat által elfogadottak.

Kanadában az élelmiszer- és takarmány előállítóknak és importőröknek az úgynevezett „adatszolgáltatás az egészséges Kanadáért” információs rendszeren keresztül kell engedélyeztetni a termék forgalmazását. Ez egy biztonsági értékelési rendszer részét képezi. A mikroorganizmust tartalmazó termékekről tanulmányt kell benyújtani a forgalomba hozatal előtt, amelyben ki kell térni az előállításra, a genetikai háttérre és a felhasználás mikéntjére (Kumar és mtsai, 2015). A természetes terápiás anyagokat a gyógyhatású élelmiszerekről és a gyógyszerek szabályozásáról szóló rendelet határozza meg. Kanadában a probiotikumokat jelenleg a természetes egészséghez hozzájáruló anyagok között tartják számon, amely megállapítás a probiotikumokról szóló tanulmányokon alapul. 


\section{KÖVETKEZTETÉSEK}

A prebiotikumok használatának általános előnye, hogy a bél mikrobióták számára kedvezőbb bélkörnyezet kialakulását eredményezik, amelyek a probiotikus mechanizmusok révén jótékony hatással vannak a gazdaszervezet egészségére. Két általános értelemben vett kedvező hatás az egészséges emésztő csatorna, illetve az egészséges immunrendszer. Mindezen tulajdonságok okán kerültek ezek az anyagok előtérbe amikor az antibiotikumok betiltásra kerültek valamint az egészségtudatos táplálkozás szerepe a társadalomban felerősödött. Ez a változás magával hozta az élelmiszerjog és szabályozás fejlődését. Az ISAPP objektív, tudományos munkával segít nemzetközi szintű értékelést adni ezekről az anyagokról. A pre- és probiotikumok bevezetésére vonatkozó szabályozások földrajzi régiónként eltérőek. Mivel a pre- és probiotikumok az élelmiszeriparban és takarmányiparban egyaránt jelen vannak, szabályozásuk sok esetben összemosódik. Az EU-ban az EFSA által hozott rendeletek, az USA-ban a GRAS minősítés, Japánban a FOSHU kategóriára vonatkozó rendelkezések, míg Kanadában az élelmiszereket érintő biztonsági értékelési rendszer egytől egyig a fogyasztók védelmét, és az egységes kereskedelmi szabályoknak való megfelelést szolgálják. Mindegyik országban az élelmiszer és takarmány adalékanyagok megítélésében és engedélyezésében nagy szerepe van a tudományos társaságok értékelésének. Az ISAPP véleménye szerint a jól beállított kísérletek, a rendszeres felülvizsgálatok és a meta analízisek meggyőző bizonyítékot szolgáltatnak a probiotikumok előnyeiről, beleértve azokat is, amelyek értékes közegészségügyi következményekkel járnak (Hill és $m$ tsai, 2014). Ezeket az értékeléseket és az ezek alapján hozott törvényi előírásokat meghatározott időnként felülvizsgálják és módosítják a tudomány és a fogyasztói igények fejlődésével megegyezően.

\section{KÖSZÖNETNYILVÁNÍTÁS}

A publikáció elkészítését az EFOP-3.6.3-VEKOP-16-2017-00005 számú projekt támogatta. A projekt az Európai Unió támogatásával, az Európai Szociális Alap társfinanszírozásával valósult meg.

\section{IRODALOM}

Floch M. H. (2018) The role of prebiotics and probiotics in gastrointestinal disease, Gastroenterol Clin N 471 179-191 DOI:10.1016/j.gtc.2017.09.011

Fuller R. (1989) Probiotics in man and animals. J Appl Bacteriol. 66. 365-378

Gibson C. R.,Roberfroid M. B. (1995) Dietary modulation of human colonic microflora: introducing the concept of prebiotics. J Nutr 125. 401 
Hill C., Guarner F., Reid G., Gibson R. G. , Merenstein J. D., Pot B., Morelli L., Canani R. B., Flint H. J., Slminen S., Calder P. C., Sanders M. E. (2014) The International Scientific Association for Probiotics and Prebiotics concensus statement on the scope and appropriate use of the term probiotic. Nat Rev Gastro Hepat 11. 506-514 DOI: $\underline{10.1038 / \text { nrgastro.2014.66 }}$

Kumar H., Salminen S., Verhagen H., Rowland I., Heimbach J., Banares S., Young T., Nomoto K., Lalonde M.(2015) Novel probiotics and prebiotics: road to the market. Curr Opin Biotech 32. 99-103 DOI: $\underline{10.1016 / j . c o p b i o .2014 .11 .021 ~}$

Loveren H.,Sanz Y., Salminen S. (2012) Health claims in europe: probiotics and prebiotics as case examples. Annu Rev Food Sci T3. 247-261. DOI: 10.1146/annurev-food-022811-101206

Ojansivu I., Ferreira C. L., Salminen S., (2011) Yacon, a newsource of prebiotic oligosaccharide swith a history of safeuse. Trends Food Sci Tech 22. 40-46. DOI: $10.1016 /$ j.tifs.2010.11.005

Parker R. B. (1974) Probiotics, the other half of the antibiotic story. Animal Nutrition and Health 29, 4 8

Perlmutter D., Loberg K. (2017) Hogyan gyógyítja és védi agyunkat az egészséges bélflóra-egy életen át. Kossuth Kiadó

Pineiro M., Ben Embarek P. (2006) Probiotics in food - Health and nutritional properties and guidelines for evaluation, FAO Food and Nutrition Paper 85. ISSN 0254-4725

Trowell H.,Burkitt D., Heaton K. (1985)Dietaryfibre, fibre-depleted foods and disease. London: Academic Press

70/524/EGK: A Tanács irányelve (1970. november 23.) a takarmány-adalékanyagokról. (HL L 270. 1970.12.14., 1-17.) http://data.europa.eu/eli/dir/1970/524/oj Celex: 31970L0524

89/107/EGK: A Tanács irányelve (1988. december 21.) az emberi fogyasztásra szánt élelmiszerekben felhasználásra engedélyezett élelmiszer-adalékanyagokra vonatkozó tagállami jogszabályok közelítéséről (HL L 40., 1989.2.11., 27-33.) http://data.europa.eu/eli/dir/1989/107/oj Celex: 31989L0107

90/496/EGK: A Tanács irányelve (1990. szeptember 24.) az élelmiszerek tápértékjelöléséről(HL L 276, 06/10/1990 0040 - 00494) http://data.europa.eu/eli/dir/1990/496/oj Celex: 31990L0496

93/5/EGK: A Tanács 93/5/EGK irányelve (1993. február 25.) az élelmiszerekre vonatkozó kérdések tudományos vizsgálatában a tagállamok által a Bizottságnak nyújtott támogatásról és a tagállamok együttműködéséről. (HL L 52., 1993.3.4., 18-21.) http://data.europa.eu/eli/dir/1993/5/oj Celex: 31993L0005

178/2002/EK: Az Európai Parlament és a Tanács 178/2002/EK rendelete (2002. január 28.) az élelmiszerjog általános elveiről és követelményeiről, az Európai Élelmiszerbiztonsági Hatóság létrehozásáról és az élelmiszerbiztonságra vonatkozó eljárások megállapításáról (HL L 31., 2002.2.1., 1 24.) http://data.europa.eu/eli/reg/2002/178/oj Celex: 32002R0178

258/97/EK Az Európai Parlament és a Tanács 258/97/EK rendelete (1997. január 27.) az új élelmiszerekről és az új élelmiszer-összetevőkről. (HL L 43., 1997.2.14., 1-6.) http://data.europa.eu/eli/reg/1997/258/oj Celex: 31997R0258

767/2009/EK: Az Európai Parlament és a Tanács 767/2009/EK rendelete (2009. július 13. ) a takarmányok forgalomba hozataláról és felhasználásáról, az 1831/2003/EK rendelet módosításáról, valamint a 79/373/EGK tanácsi irányelv, a 80/511/EGK bizottsági irányelv, a 82/471/EGK, 83/228/EGK, 93/74/EGK, 93/113/EK és 96/25/EK tanácsi irányelv és a 2004/217/EK bizottsági határozat hatályon kívül helyezéséről (EGT-vonatkozású szöveg) (HLL 229., 2009.9.1., 1-28.) http://data.europa.eu/eli/reg/2009/767/oj Celex: 32009R0767

1169/2011/EK: Az Európai Parlament és a Tanács 1169/2011/EU rendelete (2011. október 25.) a fogyasztók élelmiszerekkel kapcsolatos tájékoztatásáról, az 1924/2006/EK és az 1925/2006/EK európai parlamenti és tanácsi rendelet módosításáról és a 87/250/EGK bizottsági irányelv, a 90/496/EGK tanácsi irányelv, az 1999/10/EK bizottsági irányelv, a 2000/13/EK európai parlamenti és tanácsi irányelv, a 2002/67/EK és a 2008/5/EK bizottsági irányelv és a 608/2004/EK 
bizottsági rendelet hatályon kívül helyezéséről (EGT-vonatkozású szöveg) (HL L 304., 2011.11.22., 18-63.) http://data.europa.eu/eli/reg/2011/1169/oj Celex:32011R1169

1333/2008/EK: Az Európai Parlament és a Tanács 1333/2008/EK rendelete ( 2008. december 16.) az élelmiszer-adalékanyagokról (EGT-vonatkozású szöveg) (HL L 354., 2008.12.31., 16-33.) http://data.europa.eu/eli/reg/2008/1333/oj Celex:32008R1333

1810/2005/EK: A Bizottság 1810/2005/EK rendelete (2005. november 4.) egy takarmány-adalékanyag tíz évre szóló új engedélyezéséről, egyes takarmány-adalékanyagok végleges engedélyezéséről és egyes, már engedélyezett takarmány-adalékanyagok új alkalmazásának ideiglenes engedélyezéséről (EGT vonatkozású szöveg) (HL L 291., 2005.11.5., 5-11.) http://data.europa.eu/eli/reg/2005/1810/oj Celex: 32005R1810

1831/2003/EK: Az Európai Parlament és a Tanács (EU) 1831/2003/EK rendelete (2003. szeptember 22.) a takarmányozási célra felhasznált adalékanyagokról (EGT vonatkozású szöveg) (HL L 268., 2003.10.18., 29-43.) http://data.europa.eu/eli/reg/2003/1831/oj Celex: 32003R1831

1924/2006/EK: Az Európai Parlament és a Tanács 1924/2006/EK rendelete (2006. december 20.) az élelmiszerekkel kapcsolatos, tápanyag-összetételre és egészségre vonatkozó állításokról (HL L 404., 2006.12.30., 9-25.) http://data.europa.eu/eli/reg/2006/1924/oj Celex: 32006R1924

2004/210/EK: 2004/210/EC: Commission Decision of 3 March 2004 setting up Scientific Committees in the field of consumer safety, public health and the environment (Text with EEA relevance). (HL L 66., 2004.3.4., 45-50.) http://data.europa.eu/eli/dec/2004/210/oj Celex: 32004D0210

2015/2283/EK: Az Európai Parlament és a Tanács (EU) 2015/2283 rendelete (2015. november 25.) az új élelmiszerekről, az 1169/2011/EU európai parlamenti és tanácsi rendelet módosításáról, valamint a 258/97/EK európai parlamenti és tanácsi rendelet és az 1852/2001/EK bizottsági rendelet hatályon kívül helyezéséről (EGT-vonatkozású szöveg) (HL L 327., 2015.12.11., 1-22.) http://data.europa.eu/eli/reg/2015/2283/oj Celex: 32015R2283 